\title{
GAYA KOMUNIKASI MUBALIGH DALAM SOROTAN PUBLIK
}

\author{
Yera Yulista ${ }^{1}$
}

\begin{abstract}
Abstrak
When preaching preachers will use a variety of communication styles. Communication style is a set of behaviors that can be used communicator (preachers) in conveying the message to get a certain response in certain situations anyway. Style of communication in the form of verbal and nonverbal language may be spontaneous or its use should be regulated in such a way that the purpose of the communication itself can be achieved. The figure of the preacher as a public figure is implicitly demanded by the public can provide exemplary through their behavior, then what would happen if at some time preachers bring communication styles that are considered unfit "owned / used" by them as a preacher?, regard is the author tries to analyze the style mubaligh communication that into the public spotlight.
\end{abstract}

Keywords: communication style, Social Perception, Effective Communication, Ethics Communications and Imaging

\section{PENDAHULUAN}

Dakwah dalam pandangan Islam menurut Syekh Ali Mahfudh adalah mendorong manusia agar melakukan kebaikan dan menuruti petunjuk, menyuru mereka berbuat kebajikan dan melarang dari perbuatan mungkar, agar mereka mendapatkan kebahagiaan di dunia dan di akhirat. ${ }^{2}$ Banyak indikator yang harus diperhatikan untuk keefektifan penyampaian dakwah, apabila mengacu dari elemen-elemen dasar komunikasi terdiri dari komunikator, pesan, saluran komunikasi ,komunikan, efek yang ingin dihasilkan , respon balik komunikan, serta hambatan-hambatan yang berpotensi akan mengganggu jalan penyampaian dakwah itu sendiri. Hal ini senada pengertian dakwah Islam lainnya ialah

\footnotetext{
${ }^{1}$ Dosen ASN STAIN SAS BABEL

${ }^{2}$ Ismail Tuanany, Manajemen Pers Dakwah : Graha Guru,2007. Hlm.18
} 
menyeru ke jalan Allah yang melibatkan unsur-unsur penyeru, pesan, media, metode yang diseru dan tujuan. ${ }^{3}$ Unsur penyeru dalam dakwah Islam tentunya ditujukan kepada sosok mubaligh dengan sejumlah tanggung jawab yang dipegangnya, terutama tanggungjawabnya kepada Allah Swt. Ketika seorang sudah memutuskan menjadi mubaligh maka dengan sendirinya peran strategis itu hendaknya dipegang untuk mengefektifkan penyampaian dakwah. Dakwah dikatakan berhasil/efektif jika interaksi yang terjadi antara mubaligh dengan ma'du berjalan dengan lancar hal ini tidak lepas dari komunikasi yang efektif yang dapat diartikan sebagai penerimaan pesan oleh komunikan atau receiver sesuai dengan pesan yang dikirim oleh sender atau komunikator, kemudian receiver atau komunikan memberikan respons yang positif sesuai dengan yang diharapkan ${ }^{4}$.

Mengacu pada definisi diatas pada akhirnya dapat dilihat arti penting seorang mubaligh bagaimana mereka dengan segala atribut sosok komunikatornya harus bisa menyampaikan pesan dakwah agar bisa merubah sikap serta perilaku mad'unya. Mad'u yang menjadi sosok penerima dakwah akan melihat siapa yang menjadi penyampai pesan dakwah. Biasanya mubaligh ini akan terlihat dari ciri level kesholehan yang lebih tinggi serta pemahaman agama yang lebih dalam dari mad'u. Aristoteles menyebut karakter komunikator sebagai ethos. Ethos terdiri dari fikiran baik, akhlak baik dan maksud baik (good sense, good moral character, good will) $)^{5}$ Apalagi ketika membicarakan konteks pesan dakwah yang berkaitan dengan penyampaian pesan mulia,pesan dari langit, jalan menuju kecintaan Allah Swt kepada hamba Nya maka sejumlah "paket kebaikan" seolah memang sudah harus menjadi atribut yang dimiliki oleh mubaligh misalkan fikiran yang jernih, tutur kata lembut dan santun, penampilan yang sopan, perilaku yang beretika serta atribut kebaikan lainnya. Dapat dikatakan tanggung jawab

\footnotetext{
${ }^{3}$ Aep Kusnawan et.al, Komunikasi Penyiaran Islam (Mengembangkan Tabligh Melalui Mimbar Media Cetak Radio Televisi Film dan Media Digital Cetakan Pertama, Bandung: Benang Merah Press, 2004,hlm,vii

${ }^{4}$ Herdiyan Maulana dan Gumgum Gumelar, Psikologi Komunikasi dan Persuasi, Jakarta: Akademia Permata, 2013 , hlm.161-162

${ }^{5}$ Jalaludin Rakhmat, Psikologi Komunikasi Edisi Revisi, Bandung: Rosdakarya,2002, hlm,255.
} 
mubaligh tidaklah sederhana karena mereka dianggap sebagai panutan sehingga harus ditiru sosok keshalehan mereka.

Tiap mubaligh yang melakukan dakwah tentu tidak lepas dari kekhasan gaya komunikasi yang dimiliki oleh mereka. Gaya komunikasi adalah seperangkat perilaku yang dapat digunakan komunikator dalam menyampaikan pesan untuk mendapatkan respon tertentu dalam situasi tertentu pula ${ }^{6}$ Ciri khas gaya komunikasi mubaligh pun pada akhirnya dapat dikenali hal ini tergantung dari seberapa sering intensitas mereka tampil berdakwah terlebih lagi dakwah di Indonesia semakin pesat perkembangannya diberbagai media massa maka otomatis sosok mereka pun semakin sering disoroti publik, misalkan menyoroti beberapa gaya komunikasi mubaligh dari pesan non verbal jenis artifaktual : Aa Gym ketika berdakwah lebih sering mengenakan sorban putih di kepala, Ustadz Arifin Ilham dengan kokoh putihnya, Ustadz Syekh Ali Jaber dengan jubahnya, Mama Dedeh dengan bergo (jilbab langsung).

Gaya komunikasi mubaligh ketika berdakwah tentunya tidak hanya dilihat dari penampilan fisik mereka saja tetapi bahasa verbal tidak kalah penting menjadi perhatian karena dari bahasa verbal (lisan/tulisan) ini lebih banyak menguraikan pesan dakwah itu sendiri yang kemudian dimaknai oleh mad'u ketika mereka menerima dakwah. Oleh sebab itu teknik menggunakan bahasa yang benar, tepat lalu bisa dipahami serta menyentuh mad'u adalah salah satu indikator proses dakwah itu berhasil.

Mengupas sosok mubaligh tentulah beragam, jika mubaligh itu dianggap menjadi guru spiritual maka intensitas komunikasi dengan mad'u pun dapat lebih sering terjadi hal ini dikarenakan mereka dianggap mampu untuk memberikan solusi setiap masalah yang dikaji dari sudut keagamaan. Gaya komunikasi mereka dalam memberikan tausiyah menjadi daya tarik tersendiri walaupun sejatinya dakwah bisa dilakukan oleh siapapun. Ada sejumlah orang yang memang sengaja memilih berdakwah sebagai bagian dari hidup mereka sehingga mereka dianggap sebagai pencerah, pendidik, penolong kepada jalan kebaikan yang memiliki nilai

${ }^{6}$ Riswandi,"Gaya Komunikasi Calon Presiden Pada Pemilihan Umum 2014', dalam Membaca Gaya Komunikasi Pemimpin Kita, Jakarta:Political Communication Institute, 2014, $\operatorname{hlm} .382$ 
tersendiri di mata publik. Ya kehadiran mereka adalah oase yang menyejukkan hati.

Dari guru spiritual maka otomatis identitas sebagai public figure pun akan melekat. Sosok sebagai figur publik secara tersirat dituntut oleh publik . Artinya mereka harus memberikan contoh-contoh yang baik kepada publik dalam perilaku keseharian, bisa dikatakan menuju "kesempurnaan" dalam berkepribadian, berakhlak yang mulia.Lalu bagaimana reaksi publik jika pada suatu waktu ada gaya komunikasi mubaligh yang dianggap bersebrangan dari harapan "ideal" publik? Reaksi publik tentunya akan beragam karena sosok mubaligh dianggap "sosok sempurna". Jika pada suatu waktu melakukan hal yang tidak sesuai dengan perannya sebagai pendakwah maka hal tersebut bisa menimbulkan kekecewaan ,kesedihan ataupun kemarahan.

Bagaimanapun mubaligh tetaplah manusia kadang kealpaan dapat menimpa mereka dalam situasi tertentu, yang sama dengan manusia lainnya memiliki sisi kelebihan dan kelemahan. Namun sayangnya justru sisi kelemahanlah ini kadang sulit diterima oleh sebagian publik karena dianggap tidak layak "dimiliki/dilakukan" oleh mubaligh hal ini lah pada akhirnya yang menjadi pembicaraan ditengah publik. Sosok mereka yang ramai menjadi sorotan publik tidak lepas dari kemajuan teknologi komunikasi yang membuat persebaran informasi begitu cepat. Belum lagi jika media massa menyoroti hal ini menjadi nilai berita semakin meluaslah pemberitaan tersebut bahkan mengundang semakin banyak reaksi.

Dalam dua tahun terakhir ini ada beberapa pemberitaan tentang mubaligh yang ramai dibicarakan oleh media sosial maupun media massa. Pembicaraan mereka tidak lepas dari perilaku yang telah mereka lakukan diantaranya pada saat moment mereka melakukan aktivitas berdakwah.Perilaku/tindakan adalah dimensi/komponen konatif/psikomotorik dari psikologi. ${ }^{7}$ Dari perilaku yang terekam oleh publik ini kemudian ramai dibicarakan.Diantara beberapa kejadian tersebut nama pendakwah Mama Dedeh sempat menjadi sorotan publik. Mamah Dedeh diminta untuk meminta maaf pada saat menyebutkan kata "Autis" pada

\footnotetext{
${ }^{7}$ Riswandi,Psikologi Komunikasi Edisi Pertama( Yogyakarta: Graha Ilmu, 2013) hlm.13
} 
program acara Mamah dan Aa di Indosiar. Pemberitaan ini sedikit banyak berpengaruh terhadap pencitraan dai'yah ini. Kekhilafan yang dilakukan seolah sedikit memiliki posisi tawar ditengah publik artinya gaya komunikasi yang terlanjur dilakukan beliau "dianggap" telah melukai psikologis publik tertentu sehingga harus dikonfirmasikan alasan mengapa melakukan perilaku tersebut dan pada akhirnya mengharuskan beliau untuk meminta maaf kepada publik dengan bantuan media massa. Berangkat dari kasus diatas maka penulis tertarik untuk menganalisis dari kajian teoritis terkait dengan gaya komunikasi mubaligh yang menjadi sorotan publik tanpa bermaksud untuk memperkeruh/ menjatuhkan citra mubaligh ataupun menimbulkan masalah baru lagi terkait hal ini .

\section{A) MACAM GAYA KOMUNIKASI}

Gaya komunikasi dapat terjadi secara spontanitas tanpa diatur dulu namun ada juga yang memang sengaja diatur dalam kondisi tertentu untuk tujuan tertentu pula. Selain itu hal yang perlu diketahui dari gaya komunikasi adalah ada gaya komunikasi yang dapat berlaku baik secara lokal maupun universal. Secara lokal artinya simbol gaya komunikasi belum tentu sama pemaknaan nya antar suatu tempat namun ada juga yang sifatnya universal artinya pemaknaan simbol gaya komunikasi sama alias mendunia. Berikut beberapa bagian dari gaya komunikasi tersebut:

\section{I.Komunikasi Verbal}

Simbol atau pesan verbal adalah semua jenis simbol yang menggunakan satu kata atau lebih. Suatu sistem kode verbal disebut bahasa. Bahasa dapat didefinisikan sebagai seperangkat simbol, dengan aturan untuk mengkombinasikan simbol-simbol tersebut yang digunakan dan dipahami suatu komunitas. ${ }^{8}$ Dalam komunikasi verbal bahasa yang digunakan adalah bahasa lisan maupun tulisan. Menurut Larry L Barker bahasa memiliki tiga fungsi pertama penamaan (naming atau labeling) yakni merujuk pada usaha mengidentifikasi objek, tindakan, atau orang dengan menyebut namanya sehingga dapat dirujuk dalam komunikasi, kedua fungsi interaksi yang menurut Berker adalah 2009.hlm.260

8 Deddy Mulyana, Ilmu Komunikasi Suatu Pengantar, Bandung: Rosdakarya, 
menekankan berbagi gagasan dan emosi yang dapat mengundang simpati dan pengertian atau kemarahan dan kebingungan dan ketiga adalah fungsi transmisi informasi yakni melalui bahasa informasi dapat disampaikan kepada orang lain. ${ }^{9}$

Hal lain yang perlu dilihat bahasa verbal juga memiliki keterbatasan diantaranya 1) Keterbatasan jumlah kata yang tersedia untuk mewakili objek.Kata-kata adalah kategori-kategori untuk merujuk pada objek tertentu:orang, benda, peristiwa, sifat, perasaan dan sebagainya.Tidak semua kata tersedia untuk merujuk pada objek 2)Kata-kata bersifat ambigu dan kontekstual. Kata-kata bersifat ambigu karena kata-kata mempresentasikan persepsi dan interpretasi orang-orang yang menganut latar belakang sosial budaya yag berbedabeda.Oleh karena itu terdapat berbagai kemungkinan untuk memaknai kata-kata tersebut 3)Kata-kata mengandung bias budaya. Bahasa terikat oleh konteks budaya.Jadi bahasa yang berbeda sebenarnya mempengaruhi pemakainya untuk berpikir, melihat lingkungan dan alam semesta di sekitarnya dengan cara yang berbeda, dan karenanya berperilaku secara berbeda pula.4) Percampuradukan fakta, penafsiran dan penilaian. Dalam berbahasa kita sering mencampuradukkan fakta (uraian), penafsiran (dugaan) dan penilaian. ${ }^{10}$

\section{Komunikasi Nonverbal}

Menurut Larry A.Samovar dan Richard E.Porter komunikasi nonverbal mencakup semua rangsangan(kecuali rangsangan verbal) dalam suatu setting komunikasi yang dihasilkan oleh individu yang mempunyai nilai potensial bagi pengirim atau penerima. ${ }^{11}$ Jalaludin Rakhmat (1994) mengelompokkan pesanpesan nonverbal ke dalam : 1.Pesan Kinestik 2.Pesan Gestural 3.Pesan Proksemik 4.Pesan Artifaktual 5.Pesan Paralingustik 6. Pesan sentuhan dan bau-bauan:

\footnotetext{
${ }^{9}$ Deddy Mulyana, Ilmu Komunikasi Suatu Pengantar, Bandung: Rosdakarya, 2009.hlm.266-267

${ }^{10}$ Ibid., .hlm.269-279

${ }^{11}$ Ibid., .hlm.343
} 


\section{a.Pesan Kinestik}

Pesan kinestik adalah pesan nonverbal yang menggunakan gerakan tubuh yang mengandung arti.Pesan kinestik terdiri dari tiga komponen utama yakni a.pesan fasial yang menggunakan air muka ,b.pesan gestural dan c.pesan postural. Dale $\mathrm{G}$ Leathers (1976) menyimpulkan penelitian-penelitian tentang wajah sebagai berikut: a) Wajah mengkomunikasikan penilaian dengan ekspresi senang dan tidak senang, yang menunjukkan apakah komunikator memandang objek penelitiannya baik atau buruk b) Wajah mengkomunikasikan berminat atau tidak berminat pada orang lain atau lingkungan c) Wajah mengkomunikasikan intensitas keterlibatan dalam situasi d) Wajah mengkomunikasikan tingkat pengendalian individu terhadap pernyataan sendiri dan e)Wajah barangkali mengkomunikasikan adanya atau kurang pengertian

\section{b. Pesan Gestural}

Pesan gestural/postural berkenaan dengan keseluruhan anggota badan, makna yang dapat disampaikan adalah a) Immediacy yaitu ungkapan kesukaan dan ketidaksukaan terhadap individu yang lain b) Power mengungkapkan status yang tinggi pada diri komunikator c) Responsivness adalah gerakan anggota badan dari individu dapat reaksi secara emosional pada lingkungannya secara positif dan negatif.

\section{c. Pesan Proksemik}

Pesan prolsemik disampaikan melalui pengaturan jarak dan ruang. Umumnya dengan mengatur jarak kita mengungkapkan keakraban dengan orang lain

\section{d. Pesan Artifaktual}

Pesan artifaktual diungkapkan melalui penampilan tubuh, pakaian dan kosmetik. Walaupun bentuk tubuh relatif menetap, orang sering berperilaku dalam hubungan dengan orang sesuai dengan persepsinya tentang tubuhnya (body image). 
e. Pesan Paralinguistik

Pesan paralinguistik adalah pesan nonverbal yang berhubungan dengan cara mengucapkan pesan verbal. Satu pesan verbal yang sama dapat menyampaikan arti yang berbeda bila diucapkan secara berbeda. ${ }^{12}$

-Fungsi Pesan Nonverbal

Mark L. Knapp (Jalaludin Rakhmat, 1994) menyebut lima fungsi pesan nonverbal yang dihubungkan dengan pesan verbal yaitu: 1)Fungsi repetisi yakni fungsi pengulangan gagasan yang sudah disajikan secara verbal 2) Fungsi substitusi adalah fungsi menggantikan lambang-lambang verbal 3) Fungsi kontradiksi adalah fungsi menolak pesan verbal atau memberi makna yang lain terhadap pesan verbal 4) Fungsi komplemen yakni fungsi melengkapi dan memperkaya makna pesan non verbal 5) Fungsi aksentuansi adalah fungsi menegaskan pesan verbal atau menggarisbawahinya. Aksentuansi merupakan tindakan yang ditunjukkan oleh seseorang dengan menggunakan bagian dari anggota tubuhnya disamping menggunakan kata-kata. ${ }^{13}$

\section{B) GAYA KOMUNIKASI DAN PERSEPSI SOSIAL}

Gaya komunikasi dan persepsi memiliki keterkaitan yang sangat erat . Gaya komunikasi yang digunakan oleh mubaligh dalam menyampaikan pesan dakwah akan memunculkan suatu persepsi. Adalah tugas seorang mubaligh bagaimana pada akhirnya ia dapat berusaha menyamakan persepsi yang ada dalam fikirannya sesuai dengan apa yang difikirkan oleh mad'u. Jika persamaan persepsi itu terjadi maka dakwah bisa dikatakan telah berhasil dilakukan.

Namun kadang kala persepsi diolah mad'u tidak hanya sebatas isi pesan dakwah saja , mad'u juga melakukan persepsi tersendiri terhadap sosok mubaligh yang bisa dikategorikan sebagai persepsi sosial atau persepsi orang terhadap

\footnotetext{
${ }^{12}$ Edi, Harapan dan Syarwani Ahmad, Komunikasi Antarpribadi Perilaku Insani dalam Organisasi Pendidikan, Jakarta: Rajawali Pers, 2014.hlm.30-32

${ }^{13}$ Ibid., .hlm.33-34
} 
orang lain adalah proses menangkap arti objek-objek sosial dan kejadian-kejadian yang di alami dalam lingkungannya dan perlu digarisbawahi setiap orang mempunyai persepsi yang berbeda terhadap lingkungan sosialnya ${ }^{14}$

Beragam gaya komunikasi yang ditunjukkan mubaligh maka akan berpotensi menimbulkan banyak persepsi sosial pula karena pada dasarnya setiap individu memiliki pandangan, pemikiran dan latar belakang pengalaman yang berbeda. Berikut beberapa prinsip persepsi sosial: ${ }^{15}$

\section{1)Persepsi Berdasarkan Pengalaman}

Pola perilaku manusia didasarkan pada persepsi mereka mengenai realitas sosial yang telah dipelajari. Persepsi manusia terhadap seseorang,objek atau kejadian atau reaksi mereka terhadap hal-hal tersebut didasarkan pada pengalaman masa lalu mereka berkaitan dengan orang,objek atau kejadian serupa.Ketiadaan pengalaman terdahulu dalam menghadapi suatu objek akan membuat seseorang menafsirkan objek tersebut hanya berdasarkan dugaan.

\section{2) Persepsi Bersifat Selektif}

Atensi pada suatu rangsangan/stimulus merupakan faktor utama yang menentukan selektivitas atas rangsangan itu. Ada 2 faktor yang mempengaruhi atensi yaitu faktor internal dan faktor eksternal. Atensi yang dipengaruhi oleh faktor internal diantaranya adalah faktor biologis (lapar, haus, dsb), faktor fisiologis (tinggi, pendek, sakit, lelah, cacat fisik dsb), faktor sosial budaya (agama, etnis, pekerjaan, penghasilan, pengalaman masa lalu dsb) dan fakstor psikologis ( keinginan, harapan, motivasi dsb) sedangkan atensi yang dipengaruhi faktor -faktor eksternal adalah gerakan, intensitas, kontras, kebaruan dan perulangan objek.

3) Persepsi Bersifat Dugaan.Oleh karena data yang diperoleh mengenai objek adalah melalui panca indra yang bersifat tidak lengkap, maka persepsi merupakan proses pemikiran yang langsung meloncat pada kesimpulan.

\footnotetext{
${ }^{14}$ Riswandi,Psikologi Komunikasi ,Yogyakarta: Graha Ilmu, 2013,hlm.50

${ }^{15}$ Ibid., hlm. .50-53
} 


\section{4) Persepsi Bersifat Evaluatif}

Persepsi tidak ada yang pernah objektif. Persepsi adalah suatu proses kognitif psikologis dalam diri orang yang mencerminkan sikap, kepercayaan, nilai dan pengharapan yang digunakan orang untuk memaknai objek persepsi.

\section{5)Persepsi Bersifat Kontekstual}

Suatu rangsangan dari luar harus diorganisir dalam diri manusia. Dari berbagai pengaruh yang ada dalam persepsi, konteks merupakan pengaruh yang paling kuat. Konteks yang mengitari kita ketika melihat seseorang, suatu objek, atau suatu peristiwa sangat mempengaruhi struktur kognitif dan juga ekspetasi kita dan oleh karena itu juga akan mempengaruhi persepsi kita.

\section{C) GAYA KOMUNIKASI DAN KOMUNIKASI EFEKTIF}

Komunikasi dapat dikatakan efektif jika mad'u dapat memahami pesan yang disampaikan oleh mubaligh dan mad'u memberikan umpan balik yang sesuai dengan pesan yang disampaikan oleh mubaligh. Komunikasi efektif menjadi tolak ukur sukses atau tidaknya berdakwah itu sendiri walaupun hidayah Allah Swt yang paling utama membuka jalan manusia untuk berubah menjadi pribadi yang sholeh. Gaya komunikasi sangat berpengaruh terhadap efektifnya kegiatan dakwah. Artinya sejumlah gaya komunikasi hendaknya dapat ditata sedemikan rupa untuk menjadi pertimbangan mubaligh dalam persiapan menyampaikan dakwah misalkan dalam penggunaan verbal lisan yang mengandung unsur persuasi yang menyentuh sisi psikologis mad'u.Karena harapan dari berdakwah adalah tidak hanya sebatas pemahaman tentang keIslaman saja namun perubahan perilaku lah yang mudah terlihat sebagai tanda bahwa kegiatan dakwah itu sudah efektif.

Apabila mubaligh melakukan komunikasi yang efektif maka menurut Stewart L.Tubbs dan Sylvia Moss maka akan menimbulkan: ${ }^{16}$

1. Pengertian yakni adanya penerimaan yang cermat dari isi stimuli seperti yang dimaksud oleh komunikator.Catatan penting seringkali pertengkaran

\footnotetext{
${ }^{16}$ Riswandi,Psikologi Komunikasi Edisi Pertama( Yogyakarta: Graha Ilmu, 2013) hlm.10-13
} 
atau konflik terjadi karena pesan kita diartikan lain oleh orang yang kita ajak bicara.

2. Kesenangan yakni tidak semua komunikasi ditujukan untuk menyampaikan informasi dan membentuk pengertian namun bagaimana komunikasi yang dilakukan oleh mubaligh menimbulkan hubungan yang akrab, hangat, dekat dan menyenangkan bagi mad'u atau yang lebih lazim dikenal dengan komunikasi fatis.

3. Memengaruhi sikap yakni kecendrungan seseorang untuk merespon atau bereaksi terhadap objek tertentu ${ }^{17}$ Dengan adanya pemahaman atas pesan yang disampaikan oleh mubaligh maka akan mempengaruhi sikap yang berujung kepada perubahan prilaku. Seorang mubaligh hendaknya dapat memunculkan gaya komunikasi persuasif untuk mempengaruhi pendapat, sikap dan tindakan lewat pendekatan psikologi komunikasi.

4. Hubungan sosial yang baik yakni menumbuhkan dan mempertahankan hubungan yang memuaskan dengan orang lain dalam hal interaksi dan asosiasi, pengendalian dan kekuasaan, serta cinta kasih.

5. Tindakan adalah bagaimana dari persuasi tersebut akan melahirkan tindakan yang dikehendaki.

Lalu bagaimana indikator dari komunikasi efektif itu sendiri?Mubaligh dapat saja menerapkan diantaranya konsep REACH dalam komunikasi efektif yakni : ${ }^{18}$

1.Respect yakni sikap menghargai setiap individu yang menjadi sasaran pesan yang kita sampaikan.Rasa hormat dan saling menghargai merupakan hukum yang pertama dalam kita berkomunikasi dengan orang lain.

2. Emphaty adalah kemampuan kita untuk menempatkan diri kita pada situasi atau kondisi yang dihadapi oleh orang lain. Salah satu prasyarat utama dalam memiliki sikap empati adalah kemampuan kita untuk mendengarkan atau mengerti terlebih dulu sebelum didengarkan atau dimengerti oleh orang lain.

\footnotetext{
${ }^{17}$ Riswandi,Psikologi Komunikasi Edisi Pertama( Yogyakarta: Graha Ilmu, 2013) hlm.12

${ }^{18}$ Ibid.., hlm.13-15
} 
3.Audible yakni pesan yang disampaikan dapat diterima oleh penerima pesan. Hukum ini mengacu pada kemampuan untuk menggunakan berbagai media maupun perlengkapan audio visual yang akan membantu agar pesan yang disampaikan dapat diterima dengan baik. Dalam komunikasi personal hal ini berarti bahwa pesan disampaikan dengan cara atau sikap yang dapat diterima oleh penerima pesan.

4. Clarity bahwa pesan harus dapat dimengerti dengan baik. Harus ada kejelasan dari pesan itu sendiri sehingga tidak menimbulkan multi interpretasi atau berbagai penafsiran yang berlainan karena kesalahan penafsiran atau pesan yang dapat menimbulkan berbagai penafsiran akan menimbulkan dampak yang tidak sederhana.

5. Humble yakni sikap rendah hati.Sikap ini merupakan unsur yang terkait dengan hukum pertama untuk membangun rasa menghargai orang lain, yang biasanya didasari oleh sikap rendah hati yang dimiliki

\section{D) GAYA KOMUNIKASI DAN ETIKA KOMUNIKASI}

Dakwah akan tetap berlangsung selama proses komunikasi antara mubaligh dan mad'u terus berjalan. Interaksi yang menampilkan gaya komunikasi mubaligh tentunya harus tetap memperhatikan sisi etika komunikasi. Etika didefinisikan sebagai studi tentang sifat umum moral dan pilihan-pilihan moral spesifik yang harus dibuat seseorang. ${ }^{19}$ Dapat dikatakan bahwa prinsip etika haruslah bermoral,berakhlak mulia karena jika prinsip tersebut sudah dimiliki mubaligh maka dalam berinteraksi dengan mad'u pun etika berkomunikasi akan muncul dengan sendirinya. Namun sebaliknya jika etika berkomunikasi itu kurang diperhatikan dikhawatirkan akan menimbulkan persoalan yang baru sehingga pencitraan mubaligh akan dipertanyakan. Richard L.Johanes mengatakan Etika memiliki tiga tujuan yaitu 1) membantu manusia untuk bertindak secara bebas dan dapat dipertanggungjawabkan 2) membantu manusia mengambil sikap dan tindakan secara tepat dalam hidup ini dan 3) tujuan akhir untuk menciptakan

${ }^{19}$ Stewart L.Tubbs, Sylvia Moss, Human Communication: Konteks-Konteks Komunikasi Cet ke IV,terj.Deddy Mulyana dan Gembirasari, Bandung: PT Remaja Rosdakarya, 2005, hlm.268 
kebahagiaan. ${ }^{20}$ Islam mengatur cara berinteraksi dengan manusia apalagi jika dikaitkan dengan mubaligh yang menyampaikan pesan dakwah tentunya harus beretika yang akan mengantarkan pada kebaikan :

"Sesungguhnya tidaklah kelemahlembutan itu ada pada sesuatu melainkan ia akan memperindahnya dan tidaklah kelemah-lembutan itu dicabut dari sesuatu ,melainkan akan memperburuknya"(HR.Muslim)

Ada beberapa prinsip dalam etika komunikasi yakni 1) prinsip keindahan yaitu manusia memerhatikan nilai-nilai keindahan dan ingin menampakkan sesuatu yang indah dalam perilakunya 2) prinsip persamaan yakni melandasi perilaku yang tidak diskriminatif atas dasar apapun 3)prinsip kebaikan yakni berupaya berbuat kebaikan dalam berinteraksi dengan lingkungannya 4)prinsip keadilan yakni kemauan yang tetap dan kekal untuk memberikan kepada setiap orang apa yang semestinya mereka peroleh 5) prinsip kebebasan yakni manusia mempunyai hak untuk melakukan sesuatu sesuai dengan kehendaknya sendiri sepanjang tidak merugikan atau mengganggu hak-hak orang lain dan 6) prinsip kebenaran yakni kebenaran yang harus dibuktikan agar kebenaran itu dapat diyakini oleh individu dan masyarakat. ${ }^{21}$

\section{E) GAYA KOMUNIKASI DAN PENCITRAAN MUBALIGH}

Merrinhe's (Hoy dan Miskel) mengartikan komunikasi adalah si pengirim menyampaikan pesan yang diinginkan kepada si penerima dan menyebabkan terjadinya tanggapan (respons) dari si penerima pesan sebagaimana yang dikehendakinya. ${ }^{22}$ Mubaligh tentunya dalam menyampaikan pesan dakwah tidak lepas dari aktivitas berkomunikasi. Aktivitas berkomunikasi untuk mengubah perilaku mad'u ini lah yang diwarnai oleh kekhasan gaya komunikasi mubaligh .

\footnotetext{
${ }^{20}$ Edi, Harapan dan Syarwani Ahmad, Komunikasi Antarpribadi Perilaku Insani dalam Organisasi Pendidikan , Jakarta: Rajawali Pers, 2014.hlm.170

${ }^{21}$ Ibid., .hlm.177-179

${ }^{22}$ Ibid., hlm. 2
} 
Gaya komunikasi adalah seperangkat perilaku antarpribadi yang terspesialisasi yang digunakan dalam suatu situasi tertentu ${ }^{23}$ Pada dasarnya ada gaya komunikasi yang memang spontan terjadi namun ada juga gaya komunikasi yang sengaja di setting untuk tujuan tertentu.Mubaligh pun begitu pada saat mereka menyampaikan pesan dakwah pastinya mereka memiliki ciri khas gaya komunikasi tersendiri yang berbeda dengan manusia lainnya karena pada dasrarnya tidak ada manusia yang sama didunia ini .Ciri khas tersebut bisa terekam dari bahasa verbal maupun non verbal yang mereka gunakan. Ciri khas dari gaya komunikasi yang dibuat mubaligh pada akhirnya akan menimbulkan pencitraan tentang mubaligh itu sendiri.Membangun pencitraan yang baik bukanlah hal yang mudah namun terkadang untuk menghancurkan pencitraan mudah saja dilakukan walaupun hanya sekejap.

Apalagi saat ini kemajuan teknologi telah memudahkan penyebaran informasi . Penyebaran informasiyang cepat semakin memperluas perambatan informasi. Dengan adanya media massa pencitraan seorang mubaligh pun mudah untuk disebarkan baik dari beragam kegiatan dakwah yang mereka lakukan atau dalam kehidupan pribadi diluar aktivitas berdakwah pun sarat menjadi pemberitaan apalagi jika gaya komunikasi tersebut dianggap "kontroversial”.

\section{F) KASUS GAYA KOMUNIKASI MUBALIGH MAMAH DEDEH DALAM SOROTAN PUBLIK}

Sosok mubaligh berpeluang besar untuk dibicarakan oleh publik. Hal ini tidak lain dikarenakan mereka adalah public figure yang banyak dikenal sebagai pendakwah, pendidik, sosok yang dipandang luar biasa karena perannya penting dalam mengantarkan kebahagiaan dunia akhirat bagi kaum muslimin. Media massa yang dengan kekuatannya dapat menyebarkan pesan secara serentak dan luas ini pun menjadi mediator untuk memancing pembicaraan publik tentang sosok mubaligh. Apalagi jika perilaku yang dilakukan oleh mubaligh ini

${ }^{23}$ Rahma Santhi Zinaida ,"Analisis Gaya Komunikasi Abu Rizal Bakri: Tinjauan Komunikasi Antarbudaya 2014', dalam Membaca Gaya Komunikasi Pemimpin Kita, Jakarta:Political Communication Institute, 2014. 
"dianggap" kurang tepat maka semakin menjadi daya tarik sendiri bagi media massa untuk mempublikasikannya sehingga pada akhirnya ramai dibicarakan publik.

Hal yang menjadi pertanyaan seperti apakah gaya komunikasi yang telah dimunculkan oleh mubaligh sehingga ramai dibicarakan publik? Pada moment apakah kejadian tersebut? perhatian ini berkaitan dengan gaya komunikasi yang digunakankan pada saat proses aktivitas dakwah berjalan namun sayangnya gaya komunikasi yang dibicarakan ke tengah publik ini adalah gaya komunikasi yang tidak seharusnya dilakukan oleh mubaligh. Berikut kasus Mama Dedeh yang terkait dengan gaya komunikasi yang sempat menjadi sorotan publik:

- Mamah Dedeh dengan Kata “Autis"

Kasus Mamah Dedeh ini sempat ramai dibicarakan oleh publik pada Juli 2015 lalu karena penyebutan kata "Autis" oleh Mama Dedeh untuk orang-orang yang gemar bermain gadget. Kata "autis" lah yang ternyata memicu sorotan publik tentang mubaligh Mamah Dedeh. Kata ini lah yang ternyata pada akhirnya harus membuat seseorang merasa tersinggung yakni seorang penyandang autisme Istiaq Mumu,di Change.Org yang mengajukan petisi online kepada Mama Dedeh dan Pihak Indosiar untuk meminta maaf. Berikut isi petisi online tersebut: ${ }^{24}$

Pada tanggal 14 Juli 2015 yang lalu, Mamah Dedeh dalam acaranya menggunakan kata "Autis" sebagai penyebutan bagi orang yang apatis terhadap lingkungannya karena terlalu asyik dengan gawai (gadget) mereka. Pengguna kata autis yang dilakukan public figure seperti pada kasus Inul (yg lalu meminta maaf), kasus band Syauqi yg menggunakannya dalam lirik lagu mereka, dapat menimbulkan efek buruk.

Alih-alih mengedukasi tentang austime sebagai gangguan tumbuh kembang pada anak, hal ini malah membudayakan hal yang salah, bahwa autisme itu adalah sesuatu yang bisa dijadikan

\footnotetext{
${ }^{24}$ http://edukasi.kompas.com/read/2015/07/31/04421021/Samakan.Penyandang.Autisme.d
} engan.Orang.yang.Asyik.dengan.Ponsel.Mamah.Dedeh.Dikritik 
bahan olok-olok ejekan, sehingga masyarakat menganggap hal yang salah ini sebagai sebuah kewajaran dan dianggap biasa saja. Saya sebagai anak penyandang autis merasa sedih bahwa keistimewaan saya dijadikan bahan olok-olok atau dipakai untuk mencemooh orang lain.

Mereka tidak merasakan apa yang saya rasakan, pergulatan saya setiap hari untuk bisa memahami interaksi sosial yang terjadi di sekeliling saya, bahwa saya harus menerima ejekan karna saya berbeda. Dengan menggunakan kata "Autis" sebagai kata cemoohan, maka bertambah lagi satu mata pisau yang harus saya hadapi setiap hari yang bisa ditancapkan ke saya oleh orang-orang awam di sekitar saya.

Sebagai seorang pendakwah, seharusnya Mamah Dedeh memastikan terlebih dahulu agar ucapan yang dilontarkan oleh dia tidak menyinggung anak yang tidak bersalah ataupun melukai hati orangtua yang memiliki anak berkebutuhan khusus atau ABK.

Autisme bukan sebuah bahan lelucon, autisme bukan sebuah ejekan. Ia adalah sebuah gangguan tumbuh kembang pada anak yang memerlukan penanganan khusus dan penerimaan dari masyarakat, bukan dijadikan cemoohan atau ejekan. Atas nama anak berkebutuhan khusus autisme lainnya, saya meminta Komisi Penyiaran Indonesia mengambil tindakan yang perlu untuk melarang penggunaan kata "Autis" sebagai ejekan bagi orang yg apatis karena keasyikan menggunakan gawai, baik berupa himbauan dan/atau teguran.

Kami juga menuntut agar PT Indosiar Visual Mandiri dan Mamah Dedeh mengeluarkan permintaan maaf secara publik karena menggunakan kata "autis" secara sembarangan, dan tidak lagi mengulangi hal tersebut. Kami meminta agar Mamah Dedeh maupun para pendakwah, selebritis dan pembawa acara tidak menggunakan kata autis secara sembarangan. Hormati Anak Berkebutuhan Khusus. Mereka berhak dihormati layaknya manusia lainnya.

Dari data yang ditemukan penulis melalui situs online terkait kasus ini bertuliskan:

"Maap, saya sekarang lihat banyak orang yang autis gara-gara HP (handphone). Ada sodaranya, ada lakinya, ada anaknya, ngariung duduk, cengar-cengir aja sendirian begini, kayak orang gokil," ujarMamah Dedeh. ${ }^{25}$

25 http://bangka.tribunnews.com/2015/07/31/mamah-dedeh-dikritik-karena-samakanautis-dengan-orang-asyik-main- diakses 6 Oktober 2015 
Dari kasus ini apabila dilihat dari sudut komunikasi seorang mubaligh adalah seorang komunikator yang ketika menyampaikan pesan dakwah tentunya berisi seruan untuk melakukan kebajikan diantaranya dalam bermuamalah. Sosok mubaligh dianggap memiliki integritas dan kredibilitas yang tinggi sebagai sosok komunikator yang handal yang dianggap sangat memahami bagaimana berprilaku yang baik sehingga memang layak untuk dicontoh. Maka tidaklah mengherankan jika mubaligh sama dengan kalangan public figure lainnya yang bisa lebih banyak diidolakan, disanjung,dipuji oleh publik. Selama mereka menjadi figur publik selama itulah sosok mereka akan menjadi sorotan publik salah satunya "gaya komunikasi" yang jelas terlihat dari sosok mubaligh yang setiap mereka berinteraksi gaya tersebut akan digunakan, apalagi jika gaya komunikasi yang dianggap "menyinggung" perasaan seseorang semakin rentan menjadi sorotan publik.

Gaya komunikasi dan isi pesan adalah dua hal yang sangat erat kaitannya. Kata "autis" yang merupakan satu kata dari sekian banyak bahasa verbal yang digunakan Mamah Dedeh pada saat berdakwah harus mengantarkannya pada suatu tindakan klarifikasi dan permintaan maaf kepada publik.Penggunaan kata "autis" adalah bagian dari bahasa disepakati ditujukan kepada anak yang mengalami gangguan tumbuh kembang. Karena penggunaan kata autis dan pemaknaan itu telah menjadi kesepakatan sosial maka dapat dimaklumi jika hal itu dianggap sebagai sebuah ejekan jika digunakan penggunaan katanya pada “objek” yang tidak tepat dalam hal ini " orang yang gemar bermain HP”.

Penggunaan kata "autis" ternyata tidak hanya berfungsi sebagai penamaan saja seperti yang dikatakan oleh Larry L Barker namun juga berfungsi sebagai hasil interaksi yang memunculkan emosi berupa rasa tersinggung oleh publik(mad'u). Tidak cukup disitu dari kasus ini dapat juga menggambarkan adanya sisi keterbatasan dari bahasa verbal yang "kurang tahu" memberikan penamaan seperti apa bagi "seseorang yang sudah terlalu asyik dengan HP sehingga mengabaikan orang disekitaranya" akhirnya akibat dari kurang tepatnya penempatan penggunaan kata tersebut menimbulkan ambiguitas dari pelaku komunikasi dalam hal ini ada yang mempersepsi sebagai sebuah ejekan. Inilah 
juga yang menjadi keterbatasan bahasa dimana kata-kata menjadi bias budaya artinya bahasa terkait dengan konteks budaya. Penamaan kata "autis " yang ditujukan untuk orang yang mengabaikan lingkungan disekitarnya karena asyik dengan HP seolah sudah dilabelkan "menjadi panggilan/penamaan" walaupun tidak semua publik menggunakan ini namun penulis sepakat penamaan "autis" tidak cocok dialamatkan kepada objek mereka yang terlalu asyik dengan HP dengan mengabaikan sekelilingnya.

Menurut hemat penulis harusnya ada penamaan lain untuk objek tersebut, biarlah kata autis berikut maknanya ditempatkan pada objek yang seharusnya tanpa disamakan dengan objek/peristiwa lainnya karena ini akan berdampak pada psikologis yang menyinggung perasaan pihak lain yang mungkin mereka/keluarganya yang mengalami hal tersebut .Kata autis hanyalah tepat digunakan untuk penamaan bagi $\mathrm{ABK}$ yang mengalami gangguan tumbuh kembang saja.

Apabila mengaitkan gaya komunikasi terkait dengan penggunaan kata tersebut pun hanya diucapkan sekali alias tidak terjadi repetisi maka menunjukkan kata tersebut bisa jadi tidak menjadi perhatian utama sehingga Mamah Dedeh mungkin merasa tidak mengganggu pihak tertentu. Dalam kutipan pernyataan Mama Dedeh sebelumnya juga sudah mengucapkan kata "maaf " terlebih dulu. Menurut penulis permintaan maaf ini sebenarnya menunjukkan sikap kehatihatian yang dilakukan oleh Mama Dedeh agar tidak menyinggung perasaan siapapun.

Kasus ini juga tidak lepas dari persepsi sosial bagaimana mad'u yang mengajukan petisi seperti yang ditangkap penulis dari isi petisi yang ditulis merasa kata tersebut digunakan sebagai sebuah ejekan yang pada akhirnya menimbulkan persepsi sosial tertentu tentang sosok Mamah Dedeh. Persepsi ini tentunya timbul karena pengalaman sebelumnya yang terjadi pada dirinya yang ia merasa bahwa karena perbedaan maka itu menjadi ejekan. Dalam hal ini mad'u juga melakukan persepsi berdasarkan selektifitas karena faktor sosial budaya dan psikologis , pengalaman masa lalu dengan hal yang sama dan sebuah pengharapan 
jelas terlihat dari isi petisi yang ditulis agar kata autis tidak digunakan sebagai ejekan.

Berbicara dari sisi kefektifan komunikasi terkait peristiwa ini belum tentu dikatakan efektif karena seperti yang diungkapkan oleh Stewart L.Tubbs dan Sylvia Moss bahwa komunikasi akan dikatakan efektif jika menimbulkan perasaan senang dan hubungan sosial yang baik. Bisa dikatakan sebelum kasus ini belum selesai penyelesaiannya justru memicu kerenggangan antara salah satu mad'u dengan Mamah.Mad'u juga banyak yang kritis tidak hanya pasif dalam menerima pesan dakwah,ketika hal tersebut menyinggung psikologis mereka maka mereka bisa menyuarakan kebenarannya .Prinsip respect, empati dan humble seharusnya lebih diperhatikan oleh mubaligh agar tidak menimbulkan permasalahan. Bagaimana menghargai setiap individu dengan cara menempatkan posisi dari setiap kondisi mad'u guna mencapai keefektifan proses dakwah itu sendiri.

\section{PENUTUP}

Bahasa memiliki peran yang sangat penting sebagai alat komunikasi. Dengan bahasa maka akan mempermudah proses interaksi yang terjalin antara mubaligh dengan mad'unya. Penggunaan gaya komunikasi yang tepat akan menyukseskan penyampaian dakwah itu sendiri namun sebaliknya jika gaya komunikasi tersebut kurang tepat digunakan maka akan menimbulkan masalah lainnya padahal jika dilihat kasus ini sebenarnya hanyalah dilihat dari gaya komunikasi mubaligh yang kurang tepat dalam penggunaan penempatan suatu kata. Oleh karena itu menjadi pembelajaran yang penting bahwa mad'u memiliki arti penting dalam perannya sebagai penerima pesan. Gaya komunikasi yang terlanjur dianggap mengecewakan publik (mad'u) bisa terjadi dan ini adalah bagian keterbatasan mubaligh sebagai manusia. Disisi lain kerendahan hati serta kelapangan dada yang dimiliki mubaligh ini bisa membentuk citra yang positif mubaligh serta prilaku mulia yang dijadikan contoh, hal ini tercermin dari 
keberanian sang dai'yah untuk mengucapkan kata maaf didepan publik lewat media massa.

"Saya mohon maaf yang sebesar-besarnya. Sebetulnya sama sekali tidak ada niat di hati saya memperolok-olokkan kata 'autis'. Kata 'autis' yang saya gunakan sama sekali tidak bermaksud untuk mengganggu seseorang," ujar Mamah Dedeh, ditemui di kediamannya di Jakarta, Sabtu (1/8) seperti dikutip Kiss Indosiar ${ }^{26}$.

Alhamdulillah kasus ini pun dinyatakan selesai dengan kata perdamaian. Dan ini lah gambaran sisi sejati mereka sebagai mubaligh. 


\section{DAFTAR PUSTAKA}

Ahmad, Syarwani dan Harapan, Edi, Komunikasi Antarpribadi Perilaku Insani dalam Organisasi Pendidikan , Jakarta: Rajawali Pers, 2014

Gumelar, Gumgum dan Maulana, Herdiyan.Psikologi Komunikasi dan Persuasi, Jakarta: Akademia Permata, 2013

Kusnawan, Aep, et.al .Komunikasi Penyiaran Islam (Mengembangkan Tabligh Melalui Mimbar Media Cetak Radio Televisi Film dan Media Digital . Bandung :Benang Merah Press, 2004.

Mulyana, Deddy, Ilmu Komunikasi Suatu Pengantar, Bandung: Rosdakarya, 2009.

Moss,Sylvia and Tubbs, L,Stewart, Human Communication: Konteks-Konteks Komunikasi Cet ke IV,terj.Deddy Mulyana dan Gembirasari, Bandung: PT Remaja Rosdakarya, 2005

Rakhmat, Jalaludin. Psikologi Komunikasi.Edisi Revisi. Bandung: Rosdakarya, 2002.

Riswandi,'Gaya Komunikasi Calon Presiden Pada Pemilihan Umum 2014', dalam Membaca Gaya Komunikasi Pemimpin Kita, Jakarta:Political Communication Institute, 2014.

Riswandi,Psikologi Komunikasi ,Yogyakarta: Graha Ilmu, 2013.

Tuanany,Ismail. Manajemen Pers Dakwah Cetakan Pertama. : Graha Guru,2007.

Zinaida, Santhi, Rahma,"Analisis Gaya Komunikasi Abu Rizal Bakri: Tinjauan Komunikasi Antarbudaya 2014', dalam Membaca Gaya Komunikasi Pemimpin Kita, Jakarta:Political Communication Institute, 2014. 


\section{INTERNET}

http://bangka.tribunnews.com/2015/07/31/mamah-dedeh-dikritik-karenasamakan-autis-dengan-orang-asyik-main- diakses 6 Oktober 2015

http://edukasi.kompas.com/read/2015/07/31/04421021/Samakan.Penyandang.Auti sme.dengan.Orang.yang.Asyik.dengan.Ponsel.Mamah.Dedeh.Dikritik

http://showbiz.liputan6.com/read/2284580/mamah-dedeh-minta-maaf-usaisinggung-kata-autis diakses 13 Oktober 2015 